ISSN 2078-6441. Вісник Львівського університету. Серія географічна. 2013. Випуск 41. С. 193-204. Visnyk of the Lviv University. Series Geography. 2013. Issue 41. P. 193-204.

504.062.2:613.7].003.12

\author{
вітл н еонов, лен ікіпелов \\ “ кр їнський медичноїре біліт иї̈m курортологї̈ кр їни”, \\ ермонтовський пров., 6, 65014, м. дес -14, кр їн, \\ e-mail:mrik@kurort.odessa.net
}

ведено огляд літер турних джерел стосовно підходів до дослідження рекре ційного потенці лу способом б льної оцінки. екомендов но з стосовув ти цей метод для визн чення критеріїв оцінки природних територій курортів кр їни щодо їхнього м йбутнього ст тусу.

лючові слов : рекре ційний потенці л, рекре ційні ресурси, б льн оцінк, природні території курортів.

екре ція - вид діяльності, який м є чітко вир жену природно-ресурсну орієнт цію. риродні ресурси є провідним чинником, який визн ч є рекре ційне використ ння території. ід того, який н бір природних ресурсів м є територія, з лежить орг ніз ція видів і форм рекре ційної діяльності. к відомо, природні рекре ційні ресурси потрібно використовув ти бережно й економно, їх треб охороняти і примножув ти. ля цього необхідно вести їхній облік, кількісну і якісну оцінку, визн ч ти прид тність т льтерн тивність використ ння в тій чи іншій г лузі господ рств . блік ст ну природних ресурсів і з'ясув ння їхнього господ рського зн чення повинні грунтув тися н системі природно-ресурсних к д стрів, що містять сукупність відомостей про кількісний і якісний ст н природних ресурсів, їхню економічну оцінку.

ит ння комплексної кількісної т якісної оцінки природних рекре ційних ресурсів досі недост тньо вивчене, що пов'яз но з необхідністю вр хув ння в оцінці б г тьох чинників. кож з лежно від рівня ієр рхії досліджув ної сукупності рекре ційних ресурсів змінюються вр хов ні чинники і цілі оцінки. прикл д, оцінк окремого рекреційного ресурсу (родовищ мінер льних вод, клім толікув льної місцевості, поверхні водойми, морського пляжу т ін.) повинн охоплюв ти не тільки його кількісні х $\mathrm{p}$ ктеристики (дебіт води, площ рекре ційної території), й ступінь сприятливості для відповідного виду рекре ційної діяльності [31].

ш мет - про н лізув ти літер турні джерел інформ ції щодо дослідження рекре ційного потенці лу (зокрем, рекре ційних ресурсів) території з б льним методом у зв'язку з необхідністю визн чення критеріїв оцінки природних територій курортів кр їни.

екре ційний потенці л - це систем природних, історико-культурних об'єктів т їхніх вл стивостей, які використовують ( бо які можн використовув ти) у рекре ційній діяльності [33]. ін є функціон льною основою рекре ції i, в певному розумінні, їі скл довою ч стиною. цінк рекре ційного потенці лу території з свідчує, що його якісні т кількісні п р метри в поєдн нні з суспільно-геогр фічними чинник ми $є$ в жливими об'єктивними передумов ми розвитку рекре ційного комплексу регіону. ек-

(C) еонов ., ікіпелов ., 2013 
ре ційн прид тність природно- нтропогенних л ндш фтів виявляється стосовно окремих видів рекре ції. р ктер поєдн ння ресурсів і п р метри компонентів природного середовищ визн ч ють можливу спеці ліз цію бо профіль рекре ційного використ ння території [6].

екре ційн геогр фія з йм ється дослідженням територій рекре ційних систем, розробкою принципів орг ніз ції рекре ційного господ рств т основ рекре ційного природокористув ння. к відомо, територі льн рекре ційн систем - це геогр фічн систем, як скл д ється з вз ємопов'яз них підсистем: природних і культурних комплексів, інженерних споруд, обслуги, орг ну упр вління i, н решті, відпочив льників (рекре нтів), м є функціон льну і територі льну цілісність.

вітчизняній пр ктиці рекре ційн оцінк природних територі льних комплексів грунтується н методик х, пов'яз них із визн ченням міри прид тності природного середовищ для рекре ційних потреб, його стійкості т оптим льного н в нт ження н природу. оловними чинник ми, що визн ч ють рекре ційну прид тність території, є: естетичні якості, доступність, з безпеченість питною водою, можливість з доволення різних потреб відпочив льників [23].

дним з основних результ тів теоретичних досліджень сутності оцінки природноресурсного потенці лу ( ) території є висновок про іï н дзвич йно скл дний б г тоспектний х р ктер [34]. 1960-х років вітчизняні т з рубіжні вчені, що предст вляли природничі, суспільні, медико-біологічні т технічні н уки, розробили теоретикометодичні підходи до оцінки природно-рекре ційних систем, територій і ресурсів: методи рекре ційної геогр фії, методику б льної оцінки, к ртогр фічний метод, експертну оцінку, м тем тико-ст тистичні методи, методи лінійного прогр мув ння, іміт ційне моделюв ння, модель просторової дифузії, метод кл сифік ційного дерев , метод потенці лів, регресійний і ф кторний н ліз, методику визн чення економічного ефекту від с н торно-курортного лікув ння тощо [21].

цінк рекре ційних ресурсів був є диференційною т інтегр льною. иференційну оцінку д ють кожному окремому ресурсу, його вл стивості бо особливості в меж х регіону бо кр їни з г лом. нтегр льну оцінку д ють певній ділянці території, як відрізняється однорідністю і н бором дискретних з розподілом у їі меж х окремих видів ресурсів. иференційн оцінк сприяє визн ченню обсягу розвитку того чи іншого виду рекре ції, який грунтується н цьому ресурсі, інтегр льн оцінк д є змогу визн чити оптим льне співіснув ння різних видів рекре ції н певній території, з'ясув ти обмеження і допустимі н в нт ження рекре нтів н л ндш фт [31].

звич й процедур оцінюв ння природних умов т ресурсів скл д ється 3 т ких обов'язкових ет пів:

- виділення об'єктів оцінки - природних комплексів, їхніх компонентів і вл стивостей;

- виділення суб'єкт , з позиції якого роблять оцінку;

- формулюв ння критеріїв оцінки, які визн чені як м сшт бом і метою дослідження, т к і вл стивостями суб' ЄКт ;

- розробк п р метрів оцінних шк л гр д цій. к ли відобр ж ють оцінні відношення між суб'єктом т об'єктом. ожний рівень є пок зником інтенсивності вз ємодії вл стивості конкретного об'єкт зі ст ном суб'єкт . прикл д, П’ятиступінч ст шк л оцінки передумов для рекре ції м є т кі гр д ції: н йсприятливіші, сприятливі, помірно сприятливі, м лосприятливі, несприятливі [22]. йбільш використовув ними $є$ шк ли з трьох-семи ступенів, де н йсприятливіші умови оцінюються н йбільшим б - 
лом. одоймищ для куп ння оцінюють 3 п’ятиб льною шк лою. икористовують т кож словесну і в ртісну оцінки ресурсів.

жливий ет п роботи - вибір форми оцінки: якісної бо б льної. к відомо, первинною є якісн оцінк , 3 якої проводять причинно-н слідковий н ліз вз ємовпливу різних компонентів природного середовищ і господ рських чинників н рекре ційний процес, що сприяє ліпшому обгрунтув нню б льних оцінок.

рекре ційній геогр фії скл лись три основні типи оцінки природних рекре ційних ресурсів: медико-біологічний, психолого-естетичний i технологічний. едикобіологічн оцінк відобр ж є вплив природних чинників н орг нізм людини. ровідну роль тут відігр є клім т. озроблено низку методик, які д ють змогу оцінити комплекс клім тичних чинників з ур хув нням їхнього впливу н ст н орг нізму людини. формульов но критерії оцінки і розроблено п р метри оцінкових шк л гр д цій.

підст ві темпер тури повітря, з г льної хм рності т швидкості вітру виділено дв кл си погоди - сприятливу і комфортну. н логічно визн ч ють ступінь сприятливості погоди для зимових видів рекре ційної діяльності. еруючись б льними шк л ми розроблених т блиць і вр ховуючи клім тичні умови конкретного регіону, визн ч ють імовірну кількість днів зі сприятливими кл с ми погоди, що особливо в жливо для вибору місць орг ніз ції рекре ційних з нять різної трив лості.

отреб в кр сі є проявом естетичного н ч л в людині й визн ч є деякою мірою їі духовний світ. ому в р зі психолого-естетичного оцінюв ння потрібно розгляд ти емоційну дію природного л ндш фту бо його компонентів н людину. евний вплив м ють і н явні н досліджув ній території п м’ятки рхітектури. гідно з методичними основ ми естетичності л ндш фтів (з · л шниковою), системний підхід до оцінки естетичності природних комплексів передб ч є єдність принципів розробки методик.

прикл д, випр вд не з стосув ння прив тних т інтегр ційної б льних шк л, перев ги яких, порівняно з якісною оцінкою, визн чено; розгляд ють універс льні пок зники, прит м нні всім л ндш фт м конкретної групи; зн чущість окремих компонентів головно визн чен їхнім вз ємозв'язком, тому н пр ктиці кожен пок зник оцінюють індивіду льно, після чого проводять сум рну оцінку н підст ві уз г льнення всіх прив тних пок зників; сум 6 лів, отрим н в ході оцінюв ння, не є кінцевою метою оцінки, мірою якості.

цьому контексті з слуговує н ув гу досвід еликої рит нії, де н 3 г льнон ціон льному рівні виділено “н йкр сивіші території” н 3 с д х б льної оцінки природного середовищ 3 ур хув нням горизонт льного т вертик льного поділу території, лісистості, вікового і породного скл ду лісів, н явності водойм, клім тичних умов, 3 болоченості території, нтропогенного впливу н л ндш фти, н явності п м'яток істоpiї т культури. “ Йкр сивіші території” дуже популярні серед н селення і виділені в , exiї, лов ччині, сп нії, ольщі т ін. оч з погляду рекре логії мінусом т кої методики є відсутність оцінки, н прикл д, б льнеологічних ресурсів [23].

одноч с розробк т з стосув ння методик оцінки естетичності можуть бути пов’яз ні з низкою труднощів. ерш 3 все, це стосується використ ння б льних шк л. к з свідчил пр ктик, б льний підхід прийнятний для оцінки низькор нгових природних комплексів і невеликих територій. очність т коректність результ тів т кої оцінки обернено пропорційн до розмірів території л ндш фту [22].

p зі технологічного типу оцінюють прид тність території для певного виду рекре ційних з нять, т кож можливість ії інженерно-будівельного освоєння. основу оцінки прид тності територій для рекре ційних з нять потрібно бр ти, перш 3 все, 
природні умови: н явність природних ресурсів рекре ції, комфортність, т кож психолого-естетичні чинники. ожливості інженерно-будівельного освоєння визн чені н явністю тр нспортних комунік цій і б зи виробничої інфр структури. ехнологічн оцінк вр ховує вз ємодію людини і природного середовищ через “технологію” рекре ційної діяльності, де суб'єктом оцінки є рекре ційн г лузь. дн зі скл дових рекре ційного комплексу - с н торії і п нсіон ти з лікув нням, будинки т п нсіон ти відпочинку, с н торії-профіл кторії, б зи відпочинку, туристичні з кл ди [23].

етодик рекре ційної оцінки території повинн охоплюв ти вз ємопов'яз не вивчення основних спектів територі льної орг ніз ції відпочинку т передб ч ти комплексний н ліз цих спектів. ороші можливості для вирішення проблеми рекре ційної оцінки території і вибору місця для розміщення рекре ційних комплексів д $є$ п р т б г товимірної ст тистики, зокрем, методи ф кторного н лізу [19]. сю зібр ну в ході н лізув ння інформ цію можн н д в ти у формі т блиці д них, у якій рядки відповід ють безлічі територі льних одиниць, стовпці - безлічі озн к, що описують їхній екологічний ст н, рекре ційне, господ рське зн чення т ін. к форм д є змогу викон ти б льну оцінку території з всім комплексом спектів [12].

роведен колективом співробітників нституту геогр фії дослідницьк робот 3 теорії т методології рекре ційної геогр фії під керівництвом професор В. реобр женського д л змогу сформув ти основні положення в рекре ційній оцінці. о-перше, необхідно оцінюв ти якість природних умов, по-друге, - площу бо об'єкт, н який ці якості поширюються і, по-третє, - трив лість періоду, протягом якого ці якості діють. имірюв ння пропонув ли робити в б л х, які виробляють для кожної гр д ції оцінної шк ли.

тже, метод б льної оцінки широко з стосовують у рекре ційній геогр фії. собливо в тих вип дк х, коли будь-яке явище не підд ється точному вимірюв нню, одн к є потреб хоч $б$ у приблизній його оцінці, т кож тоді, коли нем є потреби в точному вимірюв нні явищ - льну оцінку д ють тим ресурс м, чинник м, вл стивостям, господ рський ефект використ ння яких в жко оцінити кількісно. ме 3 допомогою б лів оцінюють клім тичні території, естетичні й рекре ційні вл стивості л ндш фтів, комфортність клім ту, прид тність рік і озер для куп ння й водних видів туризму т ін.

льні шк ли в геогр фії розглянуто ще . рм д (1973). йпоширенішим і широко використовув ним є метод б льної оцінки . ухіної (1973) [17], що відобр ж є кількісні т якісні х р ктеристики природних умов ведення рекре ційної діяльності.

езв ж ючи н те, що втор цей метод розробляв для технологічної оцінки природнорекре ційних ресурсів, сьогодні в 6 г тьох дослідженнях $б$ льне оцінюв ння ведуть 3 чотирм спект ми: фізіологічним (ступінь комфортності природних умов для орг нізму відпочив льників), естетичним (х р ктер емоційного впливу л ндш фтів н відпочив льників), технологічним (можливість проведення певних рекре ційних 3 нять) т с ніт рно-гігієнічним (чистот грунтів, водного і повітряного 6 сейнів). 3 г льноприйнят поет пн схем б льної оцінки, 3 якою н першому ет пі визн ч ють 3 вд ння дослідження, суб'єкт і об'єкТ оцінки, н другому - відбир ють пок зники, які вр ховують в оцінці, н третьому - розробляють оцінні шк ли для окремих пок зників, н четвертому - отримують прив тні оцінки н підст ві цих шк л, н п’ятому об'єднують 3 певним принципом прив тні оцінки в 3 г льні інтегр льні, н шостому н лізують отрим ні оцінки, з'ясовують їхню відповідність ре льній ситу ції.

льні оцінки н був ють щор з ширшого з стосув ння під ч с дослідження явищ природно- і суспільно-геогр фічного х р ктеру, вдоскон люють методику їхнього 
отрим ння. б льній оцінці в жливим є розподіл б лів з гр д ціями опорної величини. . уденко, . гн тенко [11], зокрем , перекон ні в потребі б льної оцінки рекре ційних ресурсів у скл ді рекре ційного потенці лу, що д сть змогу використовув ти отрим ні оцінки в под льших обчисленнях т методик х.

. ердев т . язин [9] для визн чення рекре ційної комфортності л ндш фтів пропонують з стосовув ти систему оцінки в б л х. оч б г то вторів т ку систему оцінки тр ктують як уз г льнену, у дослідженнях рекре ційних л ндш фтів, н погляд дослідників, вон $є$ оптим льнішою, оскільки досліджують п р метри, які неможливо виміряти бсолютними м тем тичними зн ченнями. прикл д, т кі п р метри, як пок зники клім ту, густоти річкової мережі, площі, ступінь дигресії грунтового і рослинного покриву, перевищення гр ничнодопустимих концентр цій з бруднюв льних речовин, є об'єктивно вимірюв ними вн слідок м тем тичного підр хунку величин ми, тоді як т кі бстр ктні поняття, як кр с , пейз жність, не підляг ють точному м тем тичному підр хунку і можуть бути виміряні в системі б лів. ля можливості зіст вляти конкретні й бстр ктні к тегорії втори пропонують бсолютні м тем тичні величини, отрим ні вн слідок польових досліджень і опр цюв ння ст тистичних м терілів, переводити в б льну систему оцінок. об уникнути сильного уз г льнення д них і м ксим льно збільшити достовірність отрим них розр хунків, прийнято п'ятиб льну систему оцінки досліджув них п р метрів, що успішно використовують н уковці, які досліджують рекре ційні л ндш фти $[8,10]$.

ході дослідження ет пів і мех нізму оцінки конкурентоспроможності регіон льних ринків рекре ційних послуг . тр чков [27] з пропонув л для вивчення рекре ційного попиту використовув ти метод 6 льної оцінки, оскільки кожн груп п р метрів скл д ється з б г тьох пок зників, які ч сто в жно зіст вити один з одним. он н вел т блицю б льної оцінки зн чень метеоп р метрів, для оцінюв ння рельєфу рекре ційних територій використ л пок зник ступеня пейз жного різном ніття.

н логічним методом дослідниця пропонув л досліджув ти конкурентні позиції території н ринку рекре ційних послуг [28]. допомогою методу б льної оцінки вон розр хув л рівень прив бливості рекре ційних р йонів рим [29].

пр ці . езручк т . ожк [1] про н лізов но можливість оцінки прид тності цького н ціон льного природного п рку для рекре ційного природокористув ння. втори використ ли методику, розроблену . ожком [24], згідно з якою оцінку прид тності ділянок для певних видів відпочинку розр ховують з п’ятиб льною шк лою зі зн ченням 6 лів $0-4$, у якій 0 відповід є неприд тним умов м для рекре ції, 1 - м лоприд тним, 2 - умовно прид тним, 3 - прид тним, 4 - н йбільш прид тним. ли певному виду відпочинку д в ли н підст ві методу множення б льних оцінок усіх пок зників, які втори вв ж ли лімітув льними для конкретного виду. е пит ння висвітлене й у дисерт ції . езручк [2].

. ольч к зі спів вт. [16] оцінив рекре ційну сприятливість об'єктів природно3 повідного фонду олинської обл. $з$ ур хув нням пок зників 3 ліснення території т цінності лісів, об'єктів природно-з повідного фонду, н явності т ефективності використ ння лікув льних джерел. втори для спрощення розр хунків щодо всіх з зн чених чинників вибр ли оцінну шк лу від 1 до 36 лів. ля кожного з чинників скл дено відповідну к рту б льної оцінки. н слідок н кл д ння отрим них к рт розроблено к рту б льної оцінки рекре ційних територій олинської обл. лом 1 оцінено зону можливих умов рекре ції, $б$ лом 2 - р йони із середніми умов ми рекре ції, 6 лом 3 зони високих рекре ційних умов. 'ясов но, що цінні рекре ційні ресурси, н явн м - 
тері льно-технічн 6 з новий якісний рівень рекре ційного обслуговув ння.

етоди оцінки й оптиміз ції використ ння рекре ційного потенці лу досліджув в . узик [26], який уперше обгрунтув в б льну систему оцінки історико-культурних туристичних ресурсів, оцінив туристичну прид тність рекре ційних територій і об'єктів рп тського регіону, прикордонних р йонів ьвівської обл., визн чив пізн в льний потенці л сільських р йонів регіону рп т.

умському університеті розроблено інтегр льну оцінку еколого-економічного рівня території з допомогою гр фічного методу. підст ві основних видів оцінок 3 пропонов но критерії еколого-економічної оцінки території (різном ніття, рідкісність бо унік льність, н тур льність, репрезент тивність, екологічн стійкість, імовірність незвич йних природно- нтропогенних порушень, рекре ційний потенці л, продуктивність, доступність, культурно-історичн цінність, прив бливість, відновність). озроблено б льну оцінку цих критеріїв для визн чення регіону і побудов но р ді льну ді гр му, що д є змогу відобр ж ти в гомість і оцінку кожного з пок зників. ут відхилення допом гє визн чити в гомість, відкл ден довжин н б льній оцінці кожного з критеріїв. тже, площ фігури н ді гр мі іє інтегр льною оцінкою території [30].

. йдук [5] розробил методику б льної оцінки туристичного потенці лу територій, н підст ві якої оцінено туристичний потенці л ьвівської обл. ля визн чення н йперспективніших територій пріоритетного розвитку туризму втор д в б льну оцінку природних т історико-культурних туристичних ресурсів ьвівської обл. у розрізі дміністр тивних $\mathrm{p}$ йонів. розробленими оціночними критеріями т б льними шк л ми оцінюв ли якісні т кількісні п р метри двох груп ресурсів: природних (б льнеологічних, лісових, водних ресурсів, природно-з повідних об'єктів) т історикокультурних ( рхітектурних, рхеологічних, історичних п м'яток, п м'яток мистецтв , музеїв) туристичних. гідно з розробленою методикою, з пропонов но оцінюв ти ресурси $з$ 100-б льною шк лою у кожній з груп. ідповідно до зн чимості певного виду ресурсів, зн ходили розподіл б лів для них у меж х кожної з груп. ксим льну кількість $б$ лів з певним видом ресурсу присвоюв ли р йону, який з ур хув нням усіх оцінних критеріїв є лідером з цим видом ресурсу, і методом пропорції визн ч ли б л для всіх інших р йонів з нижчими пок зник ми. 100-б льною шк лою оцінюв ли окремо групу природних туристичних ресурсів т групу історико-культурних туристичних ресурсів, потім результ ти б льної оцінки кожної з груп ресурсів підсумовув ли. цінні критерії для кожного виду ресурсу в меж х певної групи туристичних ресурсів вибир ли відповідно до специфіки цих ресурсів. отрим ними б льними оцінк ми викон но групув ння р йонів $з$ туристичним потенці лом.

. олн р т . рченко [15] д ли б льну оцінку н явних туристичнорекре ційних ресурсів у кожній рекре ційній зоні к рп тської обл. кісну оцінку 3 пропонов но виконув ти в б л х, використовуючи кількісні х р ктеристики. основу $б$ льної оцінки природних туристичних ресурсів рекре ційних зон узято оцінку, 3 пропонов ну . йдук. н лізув ли дв блоки. ерший блок “природні туристичні ресурси” охоплює клім тичні умови, б льнеологічні, лісові, водні ресурси т природно3 повідний фонд. о другого блоку з числено культурно-історичні ресурси. ожен вид ресурсів оцінюв ли з допомогою оцінних критеріїв т певного методу. ксим льну кількість $б$ лів присвоюв ли рекре ційній зоні, як з ур хув нням усіх оцінних критеріїв є лідером 3 певним видом ресурсів. озподіл 6 лів для кожного з чотирьох видів 
природних туристичних ресурсів вигляд $є$ т к. ксим льн кількість 6 лів для 6 льнеологічних ресурсів - 40, оскільки мінер льні лікув льні води є н йціннішим видом рекре ційних ресурсів обл сті. екре ційній зоні, як м є н йбільшу кількість використовув них свердловин мінер льних вод, присвоюв ли 306 лів, б ли для всіх інших рекре ційних зон визн ч ли методом пропорції. вердловини мінер льних вод, які в м йбутньому можуть бути використ ні в туристично-рекре ційній сфері, дод тково д в ли 10 б лів. сі інші види ресурсів оцінюв ли з 20-б льною шк лою н логічно.

пр ці [15] н ведено т блиці щодо б льної оцінки б льнеологічних, водних ресурсів, лісів т природно-з повідного фонду рекре ційних зон к рп тської обл., т кож н д но сум рну б льну оцінку природних туристичних ресурсів рекре ційних р йонів.

p зі оцінюв ння історико-культурних ресурсів вр ховув ли н явність н території відповідних рекре ційних територій рхітектурних п м'яток, п м'яток рхеології, історії, мистецтв , музеїв. ксим льну кількість б лів (20) присвоюв ли рекре ційній зоні, як 3 ур хув нням т ких оцінних критеріїв, як тр ктивність, історичн цінність т доступність історико-культурних ресурсів, є лідером з певним видом ресурсу. кл д нням пропорції визн ч ли б льну оцінку інших рекре ційних зон у цій групі. с мкінець, для з верш льної б льної оцінки необхідно згрупув ти отрим ну кількість б лів 3 двом вид ми рекре ційних ресурсів (природних т історико-культурних). тЖе, з стосув ння з пропонов ної методики розр хунку б льної оцінки д є змогу оцінити потенці л кожної рекре ційної зони.

допомогою б льної оцінки . ейдик [3] з пропонув в визн ч ти ресурснорекре ційний рейтинг території. підст ві відповідних кількісних пок зників, експертного підходу, зн чного експедиційного досвіду, з використ нням п'ятиб льної шк ли визн ч ли кту льні т потенційні рекре ційно-туристичні ресурси території кр їни по обл стях з виділенням семи основних ресурсно-рекре ційних блоків (суспільногеогр фічний, природний, природно- тропогенний, рхітектурно-історичний, інфр структурний, біосоці льний, подієвий), які оцінюв ли в мплітуді 1-5 б лів. ля зручності оцінки визн ч ли мінім льний т м ксим льний критерії (кр йні позиції - 1 і 5 лів). деяких вип дк х 6 льну оцінку відповідного рекре ційного ресурсу (спелеологічні, рослинні ресурси т ін.) проводили з декільком скл довими. нтегр льний б л визн ч ли р нжув нням (теж з п'ятиб льною системою) сум скл дових 6 льних оцінок.

етодику оцінки історико-культурних туристичних ресурсів н підст ві б льного підходу н ведено в пр ці [13]. утність б льного підходу оцінки історико-культурних ресурсів поляг є в тому, що оцінні шк ли побудов но н под льшій структуриз ції видових компонентів відповідно до історико-культурної в жливості явищ, що їх х р ктеризують, і ч су, необхідного для огляду т ких об'єктів. еобхідний ч с огляду визн ч ють спеці лісти-експерти. им більше ч су потрібно для пізн ння об'єкт, тим вищ пізн в льн цінність, це озн ч є, що вищий оцінний б л йому присвоюють. 3 пропонов ній методиці под но 13 підгруп, які отрим но вн слідок структуриз ції п'яти підвидів історико-культурних туристичних ресурсів. ожн з підгруп м є логічний н бір пок зників, які оцінюють 3 п’ятиб льною шк лою. ступний ет п оцінки пов'яз ний з об'єдн нням покомпонентних б лів окремих компонентів оцінок, які отрим но щодо окремих блоків історико-культурних туристичних ресурсів, в інтегр льну величину. підсумку отримують з г льну суму б лів, як й х р ктеризує пізн в льну цінність окремого поселення бо місцевості. к доведено, з пропонов н методик оцінки п м'яток, що н леж ть до історико-культурної сп дщини укр їнського 
н роду, д сть змогу якн йповніше визн чити туристично-пізн в льний потенці л окремого поселення, місцевості, p йону, що сприятиме ефективному функціонув нню т прибутковості суч сної індустрії туризму.

дослідженні [18] розроблено методику комплексної б льної т в ртісної оцінки рекре ційних територій иєв . прикл д, виділено три оцінні к тегорії якості природно- нтропогенних чинників: сприятливу, обмежено сприятливу т несприятливу.

льну оцінку рекре ційних ресурсів міст формув ли відповідно до тези про одн кову цінність одного б лу оцінки для всіх чинників. к б зу б льної оцінки прийнято оцінку якості повітря (с ніт рно-гігієнічний чинник оцінки). мовно визн чено, що сприятливі для рекре ції х р ктеристики з бруднення повітря з н явності в ньому з бруднюв льних речовин до 0,8 оцінюють у 10 л лів, обмежено сприятливі $(0,8-1,0$ ) у 5 лів, несприятливі (пон д 1 ) у 0 б лів. ході проведення б льної оцінки рекре ційних територій пропонують оцінюв ти окремі природно- нтропогенні чинники згідно з з пропонов ними критеріями. кремі б льні оцінки ст новлять у своїй сукупності комплексну б льну оцінку рекре ційної території. р ктичне зн чення отрим них результ тів поляг є в тому, що висновки і пропозиції втор спрямов но н з безпечення ефективного функціонув ння орг ніз ційно-економічного мех нізму формув ння і розвитку рекре ційного комплексу міст .

. орненьк [32] з зн чил, що рекре ційно-екологічний потенці л території (н прикл ді орг нів) оцінюють 3 допомогою системи оцінних 6 лів.

пр цях російських учених можн зн йти оцінку відтворення сосняків з лежно від основних х р ктеристик н с джень б льним методом [7], з допомогою б льної оцінки пок зників з'ясовують зн чення для віднесення лісів до зон лісоп тологічної з грози [20], гірських л ндш фтів (з п’ятиб льною шк лою) [4]. интез пр вил ухв лення рішень і методів б льної оцінки рекре ційного потенці лу території висвітлено у пр ці [25].

тже, отрим ння комплексної оцінки зводиться до н д ння пок зник м певних кількісних зн чень (б лів) з з зд легідь обр ною шк лою гр д цій. ля синтезув ння використовують дод в ння чи множення (ч сто з уведенням коефіцієнтів). ізн інтенсивність зв'язків між природою т об'єктом оцінки зумовили вихід 3 межі льтерн тивних (двоб льних) оцінок і з стосув ння розгорнутих б г тоб льних - три- т п’ятиб льних шк л (пр ці . рм нд, . ухіної т ін.) [14]. им більш кількість ступенів у шк лі, тим дет льніше розгляд ють пок зник. д ючи б льні зн чення “вл стивостям” пок зників, які розгляд ють, н д лі оцінюють їхній вплив н людину т роль у визн ченні прид тності території для будь-яких цілей, не с мі пок зники як т кі.

ур хув нням доступних у літер турі відомостей щодо використ ння б льного методу дослідження в рекре ційній геогр фії, критеріїв оцінки природних територій курортів можн $з$ пропонув ти визн ч ти з допомогою цього методу, оскільки оцінк скл дових природної території курорту не підляг є точному вимірюв нню, курорт - це комплексне утворення, одн к є потреб в приблизній оцінці його потенці лу т визн ченні м йбутнього ст тусу. роблему н д ння курортного ст тусу певній лікув льно-оздоровчій території вирішують 3 результ т ми н лізу низки чинників, головними з яких є природні лікув льні т рекре ційні ресурси, лікув льно-оздоровч інфр структур , екологічний ст н території т можливість його збереження й інші критерії. цьому вип дку можн 3 пропонув ти підр хунок 6 лів 3 кожним розробленим критерієм 3 под льшим опр цюв нням н бр ної суми т тлум ченням отрим ного результ ту. 


\section{СПИСОК ВИКОРИСТАНОЇ ЛІТЕРАТУРИ}

1. езручко . . цінк прид тності території цького н ціон льного природного п рку для рекре ційного природокористув ння [ екст] / . . езручко, . . ожко // уковий вісник олинського н ціон льного університету ім. . кр їнки. еогр фічні н уки. - 2009. - № 1. - . 201-206.

2. езручко . . колого-геогр фічне обгрунтув ння рекре ційного природокористув ння т території цького н ціон льного природного п рку [ екст] : втореф. дис... К нд. геогр. н ук: 11.00.11 / юбомир теп нович езручко; ьвівський н ціон льний ун-т ім. в н р нк .- ьвів, 2010. -25 с.

3. ейдик . . етодологія т методик н лізу рекре ційно-туристських ресурсів кр їни [ лектронний ресурс]: втореф. дис. ... д-р геогр. н ук: 11.00 .02 / лекс ндр лексійович ейдик; иїв. н ц. ун-т ім. . евченк . - ., 2004. - 36 с. - ежим доступу: http://disser.com.ua/contents/p-2/35457.html.

4. иличенко . . ценк природно-ресурсного потенци л горных л ндш фтов [ лектронний ресурс] / . . иличенко // ндш фтное пл ниров ние. бщие основ ния. етодология. ехнология: руды еждун. школы-конф. - ежим доступу: http://www.landscape.edu.ru/files/sbornikLP/Bilichenko.pdf.

5. йдук . . кономічне регулюв ння розвитку сфери туристичних послуг [ лектронний ресурс] : втореф. дис. ... к нд. екон. н ук: 08.02.03 / нн огд нівн йдук; ерж. ун-т “ ьвів. політехнік”. - ьвів, 1999. - 19 с. - ежим доступу: http://tourlib.net/aref_tourism/gajduk.htm.

6. орб ль . екре ційний потенці л як об’єКт н укового н лізу в суспільній геогр фії [ лектронний ресурс] / . орб ль // існик ьвів. ун-ту. ерія геогр фічн . - 2007. - ип. 34. - . 52-55. - ежим доступу: http://www.lnu.edu.ua/faculty/ geography/Publik/Period/visn/34/Gorban.pdf

7. урский . . ценк естественного возобновления сосняков узулукского бор в 3 висимости от основных х $\mathrm{p}$ ктеристик н с ждений б льным методом [ лектронний ресурс] / . . урский, . . фонов, . . урский. - ежим доступу: http://science-bsea.narod.ru/2005/les_2005/gursky_ocenka.htm.

8. встропьев - . омплексный мониторинг территори льных рекре ционных систем [ екст] / . . встропьев , . . ященко // роблемы регион льной экологии. - 2001. - № 5. - . 73-85.

9. ердев . . етодическое обеспечение сб л нсиров нного упр вления рекре ционным природопользов нием [ лектронний ресурс] / . . ердев, . . язин // естник оронежского госуд рственного университет . ер. еогр фия. еоэкология. - 2003. - № 2. - ежим доступу: http://www.vestnik.vsu.ru/pdf/geograph/2003/ 02/zherdev.pdf.

10. вонин . . есн я рекреология [ екст] / . . вонин, . . вдотин, · . еньковский. - овочерк сск, 1999. - 196 с.

11. гн тенко . . риродно-ресурсный потенци л территории. еогр фический н лиз и синтез / . . г гн тенко, . . уденко. - ьвов : ищ шк., 1986. - 164 с.

12. люшкин . . ттр ктивность л ндш фтов при проектиров нии рекре ционных комплексов [ лектронний ресурс] / . . люшкин , . . в дск я. - ежим доступу: http://dssac.ru/ knigi/node/44. 
13. $\quad$ в вців B. C. уково-методичні з с ди реформув ння рекре ційної сфери. укове вид ння / В. С. р вців, . . ринів, . . оп ч, . . узик. - ьвів, 1999. 78 c. - ежим доступу: http://tourlib.net/books_ukr/kravciv.htm.

14. очетков . . еоретико-методологические и методические спекты экологогеоморфологической оценки территории [ екст] / . . очетков // естник яз нского госуд рственного университет им. . . сенин . - 2010. - № 3. - . 106-116.

15. олн $p$. . цінк н явного туристично-рекре ційного потенці лу рекре ційних зон к рп ття [ екст] / . . олн р, . . рченко // кологічний вісник. 2008. - № 7. - . 24-29.

16. ольч $\kappa$. . цінк рекре ційної сприятливості об'єктів природно-з повідного фонду олинської обл сті [ лектронний ресурс] / . . ольч к, . . есюк, . . исковець // віт довкілля. - 2004. - ежим доступу: http://ekokremen.mvk.pl.ua/sborn2004_02_01.shtml.

17. ухин . . ринципы и методы технологической оценки природных комплексов / . . ухин . . . : ук , 1973. -96 с.

18. етренко . . колого-економічні основи формув ння т використ ння рекре ційних територій в умов х міських гломер цій [ лектронний ресурс]: втореф. дис. ... к нд. екон. н ук: 08.08.01 / гор икол йович етренко; ум. держ. ун-т. уми, 2003. - 20 с. - ежим доступу: http://www.lib.ua-ru.net/inode/p-2/34137.html.

19. оморов . . ценк привлек тельности л ндш фтов / . . оморов, . . нтеев / елокурихинск я лечебно-оздоровительн я местность. - рн ул : , 1997. -154 с.

20. ост новление основоборского городского округ енингр дской обл сти от 19.08.2009 г. № 1386 “ б утверждении есохозяйственного регл мент лесов, p cположенных н территории основоборского городского округ в гр ниц х городской черты”. - ежим доступу: http://www.sbor.ru/file/1029.doc\#_toc237951395.

21. екре ционные системы / под ред. . ироненко, . очв ров . - . : зд-во осков. госуд р. ун-т , 1986. -136 с.

22. екре ционн я геогр фия : учебно-методический комплекс / под ред. . . усков , . . олубев, . . динцов . . . , 2005. - 496 с.

23. екре ційний комплекс кр їни. - ежим доступу: http://rekreatsiya.narod.ru/ rerekreatsiunuu_kompleks.html.

24. ожко . . екре ційн оцінк гірських природно-територі льних комплексів для потреб туризму (н прикл ді кр їнських рп т) [ екст] : дис.... к нд. геогр. н ук: 11.00.11 / гор их йлович ожко; ьвівський н ціон льний ун-т ім. в н р нк . - ьвів, 2000. - 198 с.

25. $\quad$ нн . . интез пр вил принятия решений и методов б лльной оценки рекре ционного потенци л территории [ лектронний ресурс]/ . . p нч // естник дмуртского ун-т . лектронный н учный журн л. - 2006. - ып. 11. .55-62. - ежим доступу: http://vestnik.udsu.ru/2006/2006-11/vuu_06_11_07.pdf.

26. теп н узик: іобібліогр. пок жч. / укл д. . елен ; н ук. ред. т втор передм. проф. . блій; редкол.: . кимович (голов ), . омбровськ , . опик. ьвів : ид. центр ім. в н р нК , 2006. - 92 с.

27. $m p$ чков . . т пы и мех низм оценки конкурентоспособности регион льных рынков рекре ционных услуг [ лектронний ресурс] / . . тр чков .- ежим доступу: http://www.nbuv.gov.ua/Articles/KultNar/knp45/knp45_79-84.pdf. 
28. $m р$ чков . . втономн еспублік рим н ринку рекре ційних послуг (суспільно-геогр фічн оцінк конкурентних позицій) [ лектронний ресурс] : втореф. дис. ... к нд. геогр. н ук: 11.00 .02 / т ля силівн тр чков ; кр їни, н-т геогр фії. - ., 2002. - 22 с. - ежим доступу: http://disser.com.ua/contents/ 33470.html.

29. $m p$ чков . . цінк прив бливості рекре ційних р йонів рим [ лектронний ресурс] / . . тр чков // нформ ційні технології в упр влінні туристичною т курортно-рекре ційною економікою: м тері ли допов. уч сників третьої н ук.-пр кт. конф., 13-14 вересня 2007 р., м. ердянськ. - ердянськ :

“ ", 2007. - .186-190. - ежим доступу: http://ariu.berdyansk.net/departments/ econom/kafedra/Sbornik\%202007.doc.

30. $p$ сов . . кологічн ст тистик : підручник / . . p сов . - . : ентр учбової літер тури, 2008. - 392 с. - ежим доступу: http://eco.dt-kt.net/books/book12/chapter-772/.

31. оменко . . екре ційні ресурси т курортологія : н вч. посібник / . . оменко. - . : ентр н вч льної літер тури, 2007. - 312 с.

32. орненьк . ндш фтн інтерпрет ція рекре ційно-екологічного потенці лу території (н прикл ді орг нів) [ екст] / . орненьк // існик ьвів. ун-ту. ерія геогр. - 2006. - ип. 33. - . 440-443.

33. блій . . снови з г льної суспільної геогр фії / . . блій. - ьвів : ьвів. ун-ту ім. . р нк , 2003. - 444 с.

34. евченко. . еоретичні т методичні спекти оцінки природно-рекре ційного потенці лу території [ лектронний ресурс] / . . евченко // кологічні проблеми суч сності : зб. тез доповідей сеукр. н ук.-пр кт. конф., 2-4 жовтня 2007 р., м. іровогр д; укл д. . . едведєв . - іровогр д, 2007. - . 145-149. - ежим доступу: http://www.kntu.kr.ua/doc/ekolog_probl_zbirnik.pdf.

\author{
m ття: н дійшл до ред кцї 15.06.2012 \\ доопр цьов н 02.11 .2012 \\ прийнят до друку 05.12.2012
}

\title{
SCORE AS A METHOD FOR STUDYING THE RECREATIONAL POTENTIAL
}

\author{
Svitlana Leonova, Olena Nikipelova \\ Public institution "Ukrainian Scientific research Institute of Medical Reabilitation \\ and Resort Therapy Ministry of Health of Ukraine care" \\ Lermontov lane, 6, UA - 65014 Odesa-14, Ukraine, \\ e-mail:mrik@kurort.odessa.net
}

This paper reviews the literature on existing approaches to the study of the recreational potential by scoring. It is recommended to apply this method to determine the criteria for evaluating natural areas of resorts of Ukraine concerning their future status.

Key words: recreation potential, recreational resources, numerical score, natural area resorts. 


\section{ветл н еонов, лен икипелов}

“ кр инский медицинской ре билит иии икурортологии кр ины”, ермонтовский переул., 6, 65014, г. десс -14, кр ин, e-mail:mrik@kurort.odessa.net

риведено обзор литер турных источников о существующих подход х к исследов нию рекре ционного потенци л путем б лльной оценки. екомендов но применять д нный метод для определения критериев оценки природных территорий курортов кр ины относительно их будущего ст тус .

лючевые слов : рекре ционный потенци л, рекре ционные ресурсы, б лльн я оценк , природные территории курортов. 